\title{
Preparation and evaluation of Salmonella Enteritidis antigen conjugated with nanogold for screening of poultry flocks
}

\author{
Hazem Mohammed Ibrahim¹, Rafik Hamed Sayed², Wafaa Ragab Abdel-Aziz¹ and Rafik Tawfik Soliman³
}

1. Department of Bacterial Sera and Antigen Research, Veterinary Serum and Vaccine Research Institute, Abbasia, Cairo; 2. Central Laboratory for Evaluation of Veterinary Biologics, Abbasia, Cairo; 3. Department of Microbiology, Faculty of Veterinary Medicine, Cairo University, Cairo, Egypt.

Corresponding author: Hazem Mohammed Ibrahim, e-mail: dr.hazemibrahim@gmail.com Co-authors: RHS: rafikhamed1010@hotmail.com, WRA: dr.wafaa3@gmail.com, RTS: rafiksoliman108@hotmail.com Received: 10-04-2017, Accepted: 22-06-2017, Published online: 02-08-2017

doi: 10.14202/vetworld.2017.848-853 How to cite this article: Ibrahim HM, Sayed RH, Abdel-Aziz WR, Soliman RT (2017) Preparation and evaluation of Salmonella Enteritidis antigen conjugated with nanogold for screening of poultry flocks, Veterinary World, 10(8): 848-853.

\begin{abstract}
Aim: The present work aimed to develop lateral flow immunochromatographic test (LFIT) for detection of Salmonella Enteritidis (SE) specific antibodies in chicken sera.

Materials and Methods: A rapid LFIT has been developed, in which SE Group D antigen labeled with the gold chloride molecules laid on the conjugate pad. Staphylococcus aureus protein A was used as capture antibody at the test line (T) of a nitrocellulose (NC) membrane and anti-SE antigen-specific rabbit antibodies were used as capture antibody at the control line $(\mathrm{C})$ of the $\mathrm{NC}$ strip in the lateral flow layout device.

Results: Using the developed LFIT, the minimal amount of SE-specific antibodies that can be detected in chicken serum sample was 1427 enzyme-linked immunosorbent assay (ELISA) unit/100 $\mu$ l that was equal to $0.1 \mu \mathrm{g}(\mathrm{Ab}) / 100 \mu \mathrm{l}$ sample. 100 suspected serum samples collected from a poultry flock were tested with the prepared SE-LFIT kits and the locally prepared stained Salmonella antigen, and the results were compared with those obtained from examination of these samples with Salmonella Group D antibody ELISA kit as the gold standard test. The sensitivity, specificity, and accuracy of the prepared SE-LFIT antigen kits were $94.4 \%, 90 \%$, and 94\%, respectively, while those obtained with stained Salmonella antigen were $88.8 \%, 90 \%$, and $89 \%$, respectively.
\end{abstract}

Conclusion: The developed test is a simple field rapid test of high sensitivity, specificity, and accuracy that can improve and facilitates rapid field surveillance of salmonellosis among chickens.

Keywords: diagnosis, lateral flow, poultry, Salmonella Enteritidis.

\section{Introduction}

Salmonella spp. are among the most important agents of foodborne diseases worldwide. Human Salmonella outbreaks are often associated with the consumption of poultry products (meat and eggs), and one of the most prevalent serotypes associated with these products is Salmonella Enteritidis (SE) [1].

Poultry may carry some Salmonella serovars without any signs or symptoms of disease and without causing any adverse effects to the health of the bird [2]. Control of Salmonella infections in poultry is posing itself as one of the difficult problems not only for those who are concerned with poultry industry but also for public health hazard because most of the serovars of Salmonellae which poultry harbor can act as potential pathogens for man [3].

The isolation and culture of conventional detection method of Salmonella cannot meet the testing

Copyright: Ibrahim, et al. Open Access. This article is distributed under the terms of the Creative Commons Attribution 4.0 International License (http://creativecommons.org/licenses/ by/4.0/), which permits unrestricted use, distribution, and reproduction in any medium, provided you give appropriate credit to the original author(s) and the source, provide a link to the Creative Commons license, and indicate if changes were made. The Creative Commons Public Domain Dedication waiver (http:// creativecommons.org/publicdomain/zero/1.0/) applies to the data made available in this article, unless otherwise stated. requirements of quick and easy detection at the grassroots level [4].

Lateral flow tests, also known as immune-chromatographic strip (ICS) tests, are point of care tests that have reduced the time spent waiting for test results from hours to minutes utilizing immunochromatographic assay. It requires no specialized equipment, less technical training for operators and has reduced the cost of device development as well as simplicity and rapidity when compared to the conventional detection methods [5]. Because of these characteristics, the ICS test is suitable for on-site testing [6]. This technique is among the most widely used technique for detection of microbial antigen in clinical specimens such as Salmonella Enteric serovars Typhi [7], Vibrio cholera [8], Staphylococcus aureus [9], Yersinia pestis in human [10], also for detection of antibodies such as anti foot-and-mouth disease (FMD) [11], antirabies [12], and anti-O FMD [13].

The present work aimed to develop lateral flow ICS test for detection of SE specific antibodies in chicken sera. The work was planned to present a simple rapid field test of high sensitivity, specificity, and accuracy that can improve and facilitates rapid field surveillance of salmonellosis among chickens. 


\section{Materials and Methods}

\section{Ethical approval}

The approval from the Institutional Animal Ethics Committee to carry out this study was not required as no invasive technique was used.

\section{SE strain}

SE strain was kindly obtained from Bacterial Sera and Antigen Research Department at Veterinary Serum and Vaccine Research Institute, Abbasia, Cairo, Egypt. It was used for the preparation of antigen.

\section{Lateral flow immunochromatographic test} Biochemical identification of SE bacteria strain

The biochemical identification of SE was done using analytical profile index (API) 20E plate system (Biomerieux -France cat\# 20-100).

\section{Preparation of the somatic (O) antigen of SE [14]}

Briefly, SE culture in one slope agar was suspended in $5 \mathrm{ml}$ sterile glucose broth. This suspension was added to $45 \mathrm{ml}$ of sterile glucose broth in a sterile flask and thoroughly mixed and incubated at $37^{\circ} \mathrm{C}$ for $48 \mathrm{~h} .2 \mathrm{ml}$ of glucose broth culture was inoculated in Roux containing thiosulphate glycerin agar and incubated at $37^{\circ} \mathrm{C}$ for $48 \mathrm{~h}$. The bacterial growth in Roux flasks was harvested using sterile buffered formal saline and sterile glass beads. The bacterial suspension was filtered by sterile gauze to remove glass beads. The filtrate was tested for purity and morphology by staining film with Gram-stain. $700 \mathrm{ml}$ of absolute alcohol were added to $100 \mathrm{ml}$ of bacterial suspension and left undistributed for about $36 \mathrm{~h}$ until precipitation was completed. The cell suspension was centrifuged for $1 \mathrm{~h}$ at $3000 \mathrm{rpm}$. The antigen was washed 3 times by using normal saline then adjusted to $1 \mathrm{mg} / \mathrm{ml}$ by spectrophotometry.

Preparation of antisera for somatic antigen prepared in rabbit [15]

Somatic $(\mathrm{O})$ antigen of SE was mixed with equal volume of complete Freund's adjuvant. The emulsion was originally injected intradermally at a dose of $0.5 \mathrm{mg} / \mathrm{kg}$ into male rabbit. Booster doses containing antigen at a dose of $0.15 \mathrm{mg} / \mathrm{kg}$ mixed with oily incomplete Freund's adjuvant were injected $\mathrm{S} / \mathrm{C}$ in the preimmunized rabbits at $2^{\text {nd }}, 4^{\text {th }}, 6^{\text {th }}$ and $8^{\text {th }}$ week's intervals. After 10 days of the last injection, the serum containing rabbit polyclonal antibody specific to SE antigen.

Concentration and purification of polyclonal antibodies of rabbit polyclonal using the ammonium sulfate procedure [16]

The collected rabbit serum was transferred to a centrifuge tube and centrifuged for $30 \mathrm{~min}$ at $13,000 \mathrm{rpm}$ at $4^{\circ} \mathrm{C}$. The supernatant was decanted by pipetting out with a Pasteur pipette into a $25 \mathrm{ml}$ beaker. The beaker $(25 \mathrm{ml})$ containing the serum was placed on ice tray and placed over a magnetic stirrer.
$4 \mathrm{ml}$ saturated ammonium sulfate was added slowly by means of a pipette then Leaved 1 to $2 \mathrm{hr}$ at $4^{\circ} \mathrm{C}$ to ensure precipitation of all the antibody. The solution was added to centrifuge tube and Centrifuged for $1 \mathrm{hr}$ at $13,000 \mathrm{rpm}, 4^{\circ} \mathrm{C}$. Decant off the supernatant solution to beaker, while pellet was retained in the centrifuge tube. The precipitate was dissolved in a $10 \mathrm{ml}$ volume of PBS and the pellet was resuspended using a glass rod. Clamp one end of the tubing using a dialysis clamp. Fill the dissolved precipitate to approximately one half of the capacity and close the tubing with a clamp. Dialysis tubing was placed in a beaker containing PBS buffer. Then Dialyzed at least 3 hour at the desired temperature (4 C) with gentle stirring of the buffer - Place the beaker on magnetic stirrer and place the stir bar in the beaker. The dialysis buffer was changed four times during dialysis and tested the access of ammonia by barium chloride $1 \%$. The concentration of purified antibody was measured by spectrophotometer.

\section{Preparation of colloidal gold nanoparticles [17]}

Briefly, $1 \mathrm{ml}$ of $1 \%(\mathrm{~m} / \mathrm{v})$ sodium citrate solution was added to $100 \mathrm{ml}$ boiled deionized water. When the mixture was heated to boil again, $1 \mathrm{ml}$ of $1 \%(\mathrm{~m} / \mathrm{v})$ gold chloride $\left(\mathrm{HAuCl}_{4}\right)$ solution was added rapidly by constant stirring. After the color of the solution changed to wine red (in about $2 \mathrm{~min}$ ), the solution was boiled for another $10 \mathrm{~min}$. After cooling, deionized water was added until the volume reached $100 \mathrm{ml}$. The obtained gold colloid was supplemented with $0.02 \%$ $(\mathrm{m} / \mathrm{v})$ of sodium azide and stored at $4^{\circ} \mathrm{C}$. The particle diameter was checked with transmission electron microscopy (H-7650).

\section{Preparation of SE antigen conjugated with nano- gold [18]}

About $25 \mu \mathrm{l}$ of SE antigen solution $(1 \mathrm{mg} / \mathrm{ml})$ was added into $125 \mu$ l of colloidal gold solution. The mixture was incubated for $15 \mathrm{~min}$ at room temperature, and then $100 \mu \mathrm{l}$ of $10 \% \mathrm{NaCl}$ solution was added to the previous solution. The color of samples changes from wine red to blue as the concentration of antigen decreases. The optimum concentration of antigen for colloidal gold labeling was the lowest concentration of antigen solution that did not give a change in color. The optical antigen solution was equal to $200 \mu 1$. The mixture was gently mixed for $10 \mathrm{~min}$, blocked with polyethylene glycol $(20,000,1 \%[\mathrm{~m} / \mathrm{v}]$ final concentration) by stirring for another $15 \mathrm{~min}$ and centrifuged at $10,000 \times g$ for $30 \mathrm{~min}$. The gold pellets were suspended in $1 \mathrm{ml}$ dilution buffer $(20 \mathrm{mM}$ Tris/HCI buffer $(\mathrm{pH} 8.2)$ containing $1 \%[\mathrm{w} / \mathrm{v}]$ bovine serum albumin, $3 \%$ [w/v] sucrose and $0.02 \%$ sodium azide) and stored at $4^{\circ} \mathrm{C}$ until use.

Preparation of lateral flow immunochromatographic test (LFIT) [18]

- Sample pad: A glass fiber was saturated with phosphate buffered saline (PBS) solution ( $\mathrm{pH} 7.2)$ 
containing $0.3 \%$ Tween -20 and $0.5 \%(\mathrm{w} / \mathrm{v})$ triton $\mathrm{X} 100$, and dried at $37^{\circ} \mathrm{C}$ and kept under dry conditions at room temperature until used.

- The conjugate pad: It was prepared as follows: A glass fiber was treated with $0.1 \%$ Tween- 20 for $10 \mathrm{~min}$ and dried at $60^{\circ} \mathrm{C}$. The prepared glass fiber was cut into sections $(4 \mathrm{~cm} \times 0.5 \mathrm{~cm})$, and then saturated with $0.15 \mathrm{~mL}$ of SE conjugated nanogold. The conjugate pad was dried for $1 \mathrm{~h}$ at $37^{\circ} \mathrm{C}$ and stored under dry conditions at $4^{\circ} \mathrm{C}$ until used.

- Nitrocellulose (NC) membrane: The dispenser (BIODOT XYZ-3) was used to dispense two lines on the NC membrane $(25 \mathrm{~mm} \times 300 \mathrm{~mm})$. The staphylococcal protein A $(1.5 \mathrm{mg} / 0.1 \mathrm{ml})$ was dispensed around the bottom a the test line ( $1 \mu 1 / 1 \mathrm{~cm}$ line) while rabbit antibody against SE antigen $(1 \mathrm{mg} / \mathrm{ml})$ was dispensed at the upper position as the control line $(1 \mu \mathrm{l} / 1 \mathrm{~cm}$ line $)$. The distance between two lines was $5 \mathrm{~mm}$. After applying of the test line, the membrane was dried for 2-6 $\mathrm{h}$ in room temperature. Then, it was blocked by immersing the membrane in blocking buffer. After the whole membrane was wetted, it was washed by immersing it 5 times in the first PBS and 5 times in the second PBS solution. After that, the membrane was covered with top laminate and cut into 0.5 -cm-width test-strips by using an automated cutter machine.

Two red bands at the test and control zones are developed with no further addition of reagent. If the antibodies against SE in serum sample with concentration below the detection limit, only one band at the control zone is visualized. If no band developed at both zones, the test is invalid. The intensity of the test line is in proportion to the amount of antibodies against SE present in the sample. The control zone acts as a positive control to assure that functional, conjugated antigen migrated throughout the system. The total assay time is $<5 \mathrm{~min}$. The estimation of the test-strip results can either be performed visually with the naked eye.

\section{Sensitivity of the developed LFIT}

The positive standard antisera of Group D were obtained from BioChek Salmonella Group D antibody enzyme-linked immunosorbent assay (ELISA) (cat \# CK117). The positive control was purified by using the ammonium sulfate procedure [16] to get immunoglobulins only. The purified positive control was diluted (2-fold serial dilution). The dilutions were tested by LFIT $(100 \mu \mathrm{l})$ and Salmonella Group D antibody ELISA $(100 \mu \mathrm{l})$. The ELISA procedure was carried out according to kit manual. The antibodies concentration was measured for each dilution using total protein test in spectrophotometer.

\section{Specificity testing of the developed LFIT}

Standard antisera of Salmonella Pullorum (SP), Salmonella Typhimurium (ST), Mycoplasma gallisepticum (MG), Mycoplasma synoviae (MS), and Escherichia coli were tested by the prepared strip.

Determination of specificity, sensitivity, and accuracy for LFIT and locally prepared stained SE antigen by using Salmonella Group D antibody

About 100 serum samples were collected from a poultry farm. The samples were tested with LFIT and locally prepared stained SE antigen also it was tested with Salmonella Group D antibody ELISA kit. The test ELISA procedure was done according to kit manual.

Statistical analysis and evaluation of LFIT and locally prepared stained SE antigen (test validity)

Descriptive statistics

Mean and standard deviation of lateral LFIT and locally prepared stained SE antigen were determined by using the Statistix ${ }^{\circledR}$ (1996) package [19].

\section{Evaluation of two tests [20,21]}

The evaluation of two SE tests was studied as follow (Table-1):

- Sensitivity (true positive rate)

Is the ability of a test to correctly identify the percentage of the serum contains SE antibodies:

$$
\text { Sensitivity }=\frac{\mathrm{T}+}{(\mathrm{T}+)+(\mathrm{F}-)} \times 100(\text { stated as } \%)
$$

- $\quad$ Specificity (true negative rate)

Is the ability of a test correctly identifies the percentage of the serum contains SE antibodies:

$$
\text { Specifity }=\frac{\mathrm{T}-}{(\mathrm{T}-)+(\mathrm{F}+)} \times 100(\text { stated as } \%)
$$

- Accuracy (validity)

Describe the degree to which measurement reflects the true status.

Table-1: Evaluation of diagnostic kit by using Salmonella Group D antibody ELISA kit (gold standard).

\begin{tabular}{lllll}
\hline Test (LFIT) or local prepared antigen & \multicolumn{4}{l}{ Salmonella Group D antibody ELISA kit } \\
\cline { 2 - 4 } & Positive & Negative (no antibodies) & Total \\
\hline+ & $\mathrm{T}^{+}$ & $\mathrm{F}^{+}$ & $\mathrm{T}^{+} \mathrm{F}^{+}$ \\
- & $\mathrm{F}^{-}$ & $\mathrm{T}^{-}$ & $\mathrm{F}^{-} \mathrm{T}^{-}$ \\
Total & $\mathrm{T}^{+} \mathrm{F}^{-}$ & $\mathrm{F}^{+} \mathrm{T}^{-}$ & $\mathrm{T}^{+} \mathrm{F}^{+} \mathrm{F}^{-} \mathrm{T}^{-}(\mathrm{n})$ \\
\hline
\end{tabular}

Gold standard: The means by which one can detect SE antibodies whether it is truly present or not. In this study, SE. antibodies detected ELISA is the gold standard. False positive $\left(\mathrm{F}^{+}\right)$: The serum contains SE antibodies but in fact it does not contain these antibodies. False negative $\left(\mathrm{F}^{-}\right)$: The serum does not contain SE antibodies but in fact it contains SE antibodies. True positive $\left(\mathrm{T}^{+}\right)$: The serum contains SE antibodies and indeed contains SE antibodies. True negative $\left(\mathrm{T}^{-}\right)$: The serum free from SE antibodies and indeed it is free. ELISA=Enzyme-linked immunosorbent assay, LFIT=Lateral flow immunochromatographic test, $\mathrm{SE}=$ Salmonella Enteritidis 


\section{Results}

$$
\text { Accuracy }=\frac{(\mathrm{T}+)+(\mathrm{T}-)}{\text { Total number }(\mathrm{n})} \times 100(\text { stated as \%) }
$$

\section{Biochemical identification of SE bacteria strain}

The results of the biochemical identification of the Salmonella Enterica serotype Enteritidis (SE) strain used in the SE antigen preparation are shown in Table-2 and Figure-1.

\section{Sensitivity of the developed LFIT}

The minimal amount of antibodies against SE in serum sample can be detected was 1427 ELISA titer/100 $\mathrm{ml}$ that was mean $0.1 \mu \mathrm{g}(\mathrm{Ab}) / 100 \mathrm{ml}$ sample as showed in Table-3 and Figure-2.

\section{Specificity test of SE-LFIT}

The standard antisera of ST, MG, MS and E. coli. But SP antisera (Figure-3).

\section{Validity of SE-LFIT developed kits}

About 100 suspected serum poultry samples were examined separately against SE antibodies using SE-LFIT, the local prepared stained antigen and Salmonella Group D antibody ELISA kits and the results were compared.

The results of SE-LFIT as compared with the result of bacteriological examination calculated at the
$\left(\mathrm{T}^{+}\right),\left(\mathrm{F}^{+}\right),\left(\mathrm{F}^{-}\right)$and $\left(\mathrm{T}^{-}\right)$were $85,1,5$, and 9 , respectively, and for locally stained prepared antigen were 80, 1, 10, and 9, respectively, as shown in Table-4.

The sensitivity, specificity and accuracy of SE-LFIT as compared to ELISA were calculated and was found to be $94.4 \%, 90 \%$ and $94 \%$, respectively, and for locally prepared stained antigen $88.8 \%, 90 \%$ and $89 \%$, respectively, as shown in Table-4.

\section{Discussion}

Salmonella infections are considered to be the most important disease affecting poultry. The disease causes severe damage among young birds with a high mortality rate. Adult birds are often chronic carriers of Salmonella organisms without outward signs. In this work, specific Group D antigen was prepared and conjugated with nanogold that was laid on lateral flow ICS (LFIT).

The ideal diagnostic tool of SE should be able to detect the antibody in the shortest possible time, simple, sensitive, specific and inexpensive. Furthermore, it should be suitable as field test or laboratory test and can be applied on large scale of poultry.

The LFIT was low cost, fast, no requirements for skilled technicians and applicable in field condition gives results within 5 min that is helpful in large poultry flock Salmonella screening. Unfortunately,

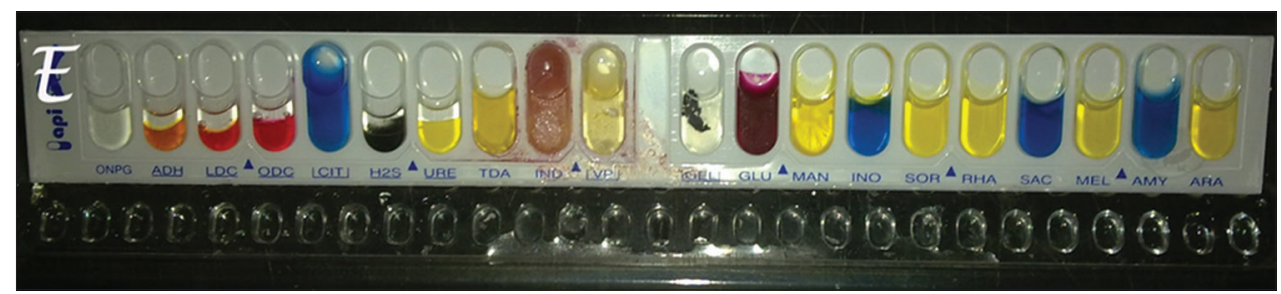

Figure-1: API system for biochemical identification of Salmonella Enteritidis bacterial strain.

Table-2: Biochemical identification of SE strain by using API system.

Biochemical ONPG ADH LDC ODC CIT H2S UREa TDA IND VP GEL GLU MAN INO SOR RHA SAC MEL AMY ARA OXY NO ${ }_{2}$ test

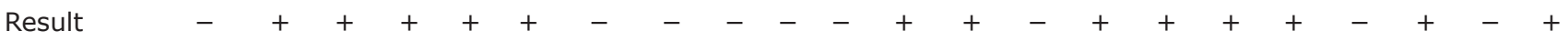

API 20E - ONPG=2-nitrophenyl-B-D-galactopyranoside, ADH=Arginine dihydrolase, $L D C=$ Lysine decarboxylation, $\mathrm{ODC}=$ Ornithine decarboxylation, $\mathrm{CIT}=$ Citrate test, $\mathrm{H} 2 \mathrm{~S}=$ Hydrogen sulfide, UREa=Urease, TDA=Tryptophan deaminase, $\mathrm{VP}=$ Voges Proskauer, GEL=Gelatin liquefaction test, $\mathrm{GLU}=$ Glucose fermentation test, MAN=Mannitol fermentation test, INO=Inositol fermentation test, $\mathrm{SOR}=$ Sorbitol fermentation test, RHA=Rhamnose fermentation test, $\mathrm{SAC}=\mathrm{Sucrose}$ fermentation test, $M E L=$ Melibiose fermentation test, $A M Y=$ Amygdalin, $A R A=$ Arabinose fermentation test, $O X=O x i d a s e$ test, $\mathrm{NO}_{2}=$ Nitrogen dioxide production, $\mathrm{SE}=$ Salmonella Enteritidis

Table-3: The sensitivity test of SE-LFIT.

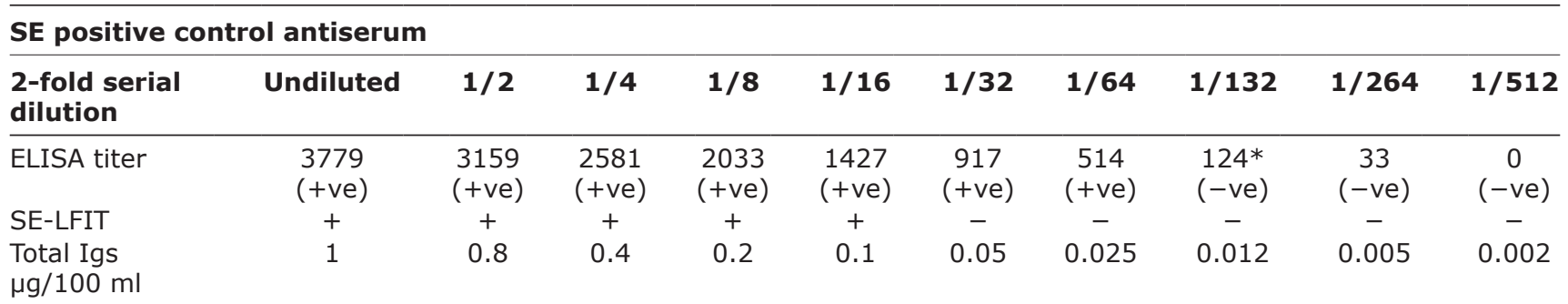

*According to ELISA kit interpretation: The titer under than 500 was considered negative. SE-LFIT=Salmonella Enteritidis-lateral flow immunochromatographic test, ELISA=Enzyme-linked immunosorbent assay, Ig=Immunoglobulin 
Table-4: Validity test for SE-LFIT and locally prepared stained antigen comparing with Salmonella Group D antibody ELISA.

\begin{tabular}{|c|c|c|c|c|c|c|}
\hline \multirow[t]{2}{*}{ Test } & \multicolumn{3}{|c|}{$\begin{array}{c}\text { Salmonella Group D } \\
\text { antibody ELISA }\end{array}$} & \multirow{2}{*}{ Sensitivity test (\%) } & \multirow[t]{2}{*}{ Specificity test (\%) } & \multirow[t]{2}{*}{ Accuracy test (\%) } \\
\hline & +ve & $-v e$ & Total & & & \\
\hline \multicolumn{7}{|c|}{ SE-LFIT } \\
\hline$+v e$ & $\left(\mathrm{~T}^{+}\right) 85$ & $\left(\mathrm{~F}^{+}\right) 1$ & 86 & 94.4 & 90 & 94 \\
\hline -ve & $\left(F^{-}\right) 5$ & $\left(T^{-}\right) 9$ & 14 & & & \\
\hline Total & 90 & 10 & 100 & & & \\
\hline \multicolumn{7}{|c|}{ Locally prepared stained antigen } \\
\hline$+v e$ & $\left(\mathrm{~T}^{+}\right) 80$ & $\left(\mathrm{~F}^{+}\right) 1$ & 81 & 88.8 & 90 & 89 \\
\hline- ve & $\left(F^{-}\right) 10$ & $\left(\mathrm{~T}^{-}\right) 9$ & 19 & & & \\
\hline Total & 90 & 10 & 100 & & & \\
\hline
\end{tabular}

SE-LFIT=Salmonella Enteritidis-lateral flow immunochromatographic test

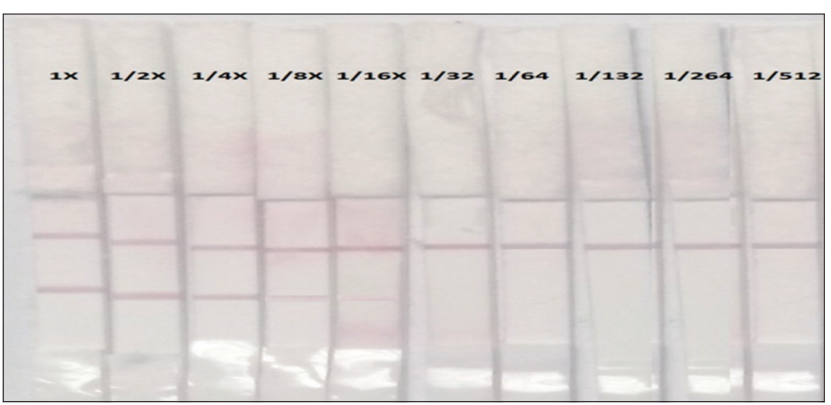

Figure-2: Sensitivity test of Salmonella Enteritidis-lateral flow immunochromatographic test.

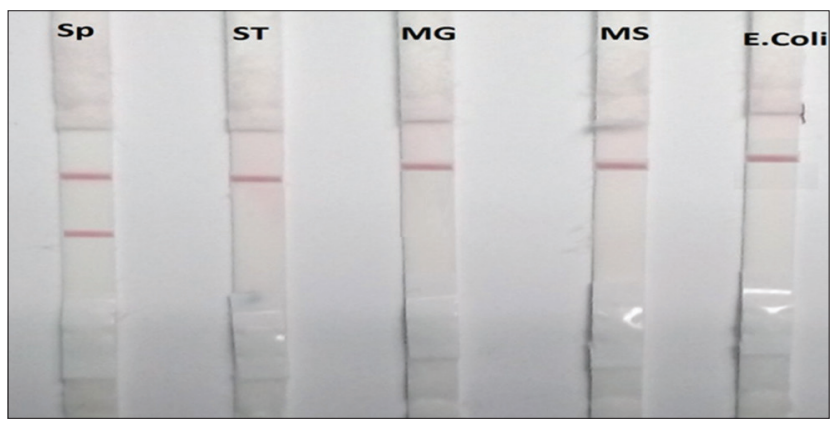

Figure-3: Specificity test for Salmonella Enteritidis-lateral flow immunochromatographic test.

the LFIT did not have ability to differentiate between SE and SP, as there is cross-reactivity between them as the both SE and SP are sharing the same somatic antigen.

The minimal amount of antibodies against SE in poultry serum can be detected using SE-LFIT was 1427 ELISA titer $/ 100 \mathrm{ml}$ or $0.1 \mu \mathrm{g} / 100 \mu 1$ in samples. Biagini et al. [22] detected $3 \mathrm{mg} / 100 \mathrm{ml}$ anti-anthrax immunoglobulin $\mathrm{G}$ in bovine serum.

The developed SE-LFIT and locally prepared antigen were validated by testing 100 poultry serum samples in comparison with Salmonella Group D antibody ELISA kit. The sensitivity, specificity and accuracy of SE-LFIT as compared to ELISA were $94.4 \%$, $90 \%$, and $94 \%$, respectively, but were $88.8 \% 90 \%$ and $89 \%$, respectively, for locally prepared stained antigen that was lower than SE-LFIT. The prepared SE-LFIT is to be used for detection of SE antibody in poultry serum as poultry serum also contains antibody against
MG, MS and E. coli, so we have to check if there is cross reaction between them or not in poultry serum regardless of affected organ.

These results are similar to those recorded by Yang et al. [13] who found that the sensitivity and specificity of lateral flow test for detection of antiFMD virus compared to anti-FMD ELISA kit were $100 \%$ and $99.1 \%$, respectively. A sensitivity rate of $100 \%$ and a specificity of $98.8 \%$ of the lateral flow strips developed for detection of anti-O serotype FMD compared to ELISA kit were reported [11]. Furthermore, there was a lateral flow test sensitivity and specificity of $88.7 \%$ and $91.9 \%$, respectively, for the detection of anti-rabies as compared with ELISA [12].

Compared with the commercially available SE antibodies diagnostic tools. The developed SE-LFIT is not only very rapid test ( $5 \mathrm{~min}$ ) but also it is simple, convenient, has long shelf time and can be used by untrained personal at poultry farm site without requirement of additional equipment. Moreover, the SE-LFIT preparation technology has been strongly improved, which will be reflected on its sensitivity and specificity. These tools are badly required for routine diagnosis in the laboratory and under field conditions.

\section{Conclusion}

The developed test is a simple field rapid test of high sensitivity, specificity, and accuracy that can improve and facilitates rapid field surveillance of salmonellosis among chickens.

\section{Authors' Contributions}

HMI and RHS designed the work. HMI, RHS, and WRA conducted the research work. Data analysis and manuscript were written by HMI, RHS and WRA under the guidance of RTS. All authors read and approved the final manuscript.

\section{Acknowledgments}

The authors are very much thankful to Veterinary Serum and Vaccine Research Institute for providing all necessary facilities for conducting this research work. 


\section{Competing Interests} interests.

The authors declare that they have no competing

\section{References}

1. Borges, K.A., Furian, T.Q., de Souza, S.N., Tondo, E.C., Streck, A.F., Salle, C.T., de Souza Moraes, H.L. and do Nascimento, V.P. (2017) Spread of a major clone of Salmonella Enterica serotype enteritidis in poultry and in Salmonellosis outbreaks in southern Brazil. J. Food Protect., 80(1): 158-163.

2. Jarquin, R., Hanning, I., Ahn, S. and Ricke, S.C. (2009) Development of rapid detection and genetic characterization of Salmonella in poultry breeder feeds. Sens. (Basel), 9(7): 5308-5323.

3. Galis, A.M., Marcq, C., Marlier, D., Portetelle, D., Van, I., Beckers, Y. and Thewis, A. (2013) Control of Salmonella contamination of shell eggs-preharvest and postharvest methods: A review. Compr. Rev. Food Sci. Food Saf., 12: $155-182$.

4. Wu, B., Zhang, X., Pan, W., Zhang, L. and Zhang, F. (2015) Determination of Salmonella Pullorum with nanoparticles immune based lateral flow strip assay. Adv. Microbiol., 5: 364-369. Available from: http://www.scirp.org/journal/ aim. Accessed on 01-11-2016.

5. Chen, W., Rahman, R.T., Antora, R.A., Saqib, N., Hossain, P., Zhang, J., Al-Hajj, N.Q., Lou, Z. and Zaixiang, L. (2015) Lateral flow test strip approaches for rapid detection of food contaminants and pathogens: Review. Am. Res. Thoughts, 1(12): 1222-1248.

6. Lata, K., Naik, L., Sharma, R. and Rajput, Y.S. (2013) Lateral flow assay-concept and its applications in food analysis. Indian Food Ind. Mag., 32(5): 22-32.

7. Pandey, S.K., Suri, C.R., Chaudhry, M., Tiwari, R.P. and Praveen, R. (2012) A gold nanoparticles based immuno-bioprobe for detection of Vi capsular polysaccharide of Salmonella Enterica Serovars typhi. Mol. Biosys., 8: 1853-1860.

8. Shyu, R., Tang, S., Chiao, D. and Hung, Y. (2010) Gold nanoparticle-based lateral flow assay for detection of staphylococcal enterotoxin B. Food Chem., 118: 462-466.

9. Hong, W., Lihua, H., Haoran, W., Jianfeng, Q., Zhaobiao, G., Chengke, X., Ziwen, Z., Youbao, Z., Zongmin, D., Yanfeng, Y., Yan, Z., Huijie, H., Ruifu, Y. and Lei, Z. (2010) Development of an up converting phosphor technology-based 10-channel lateral flow assay for profiling antibodies against Yersinia pestis. J. Microbiol.
Methods, 83: 133-140

10. Chen, W., Zhang, J., Lu, G., Yuan, Z., Wu, Q. and Li, J. (2014) Development of an immunochromatographic lateral flow device for rapid diagnosis of Vibrio cholerae O1 serotype Ogawa. Clin. Biochem., 47: 448-454.

11. Oem, J.K., Ferris, N.P., Kwang-Nyeong, L., Yi-Seok, J., Bang-Hun, H. and Jong-Hyeon, P. (2009) Simple and rapid lateral-flow assay for the detection of foot-and-mouth disease virus. Clin. Vaccine Immunol., 16(11): 1660-1664.

12. Shiota, S., Mannen, K. and Matsumoto, T. (2009) Development and evaluation of a rapid neutralizing antibody test for rabies. J. Virol. Methods, 161: 58-62.

13. Yang, W., Li, X., Liu, G., Zhang, B., Zhang, Y., Kong, T., Tang, J., Li, D. and Wang, Z. (2011) A colloidal gold probbased silver enhancement immune-chromatographic assay for the rapid detection of abrin-a. Biosens. Bioelectron., 26: 3710-3713

14. Wary, C. and Wary, A. (2000) Salmonella in domestic animals. CABI Publishing, Oxfordshire.

15. Gulbenkian, S., Wharton, J. and Polak, J.M. (1987) The visualization of cardiovascular innervations in the guinea-pig using an antiserum to protein gene product 9.5. J. Auton. Nerv. Syst., 18: 235-247.

16. Donovan, J. and Brown, P. (1995) Current Protocols in Immunology. Wiley Online Library, John Wiley \& Sons, Inc., US.

17. Singh, J., Sharma, S. and Seema, N. (2015) Evaluation of gold nanoparticle based lateral flow assays for diagnosis of Enterobacteriaceae members in food and water. Food Chem., 170: 470-483.

18. Singh, J., Sharma, S. and Seema, N. (2015) Nanogold based lateral flow assay for the detection of Salmonella Typhi in environmental water samples. Anal. Methods, 7: 9281-9288.

19. Statistix. (1996) Analytical Software, Version 1.0, Tallahassee, FL, USA.

20. Timmreck, T.C. (1994) An Introduction to Epidemiology. Jones and Bartlett Publishers, Boston, London and Singapore.

21. Thrusfield, M. (2007) Veterinary Epidemiology. $3^{\text {rd }}$ ed. Blackwell Science, London.

22. Biagini, R.E., Sammons, D.L., Smith, J.P., MacKenzie, B.A., Striley, C.A.F., Snawder, J.E., Robertson, S.A. and Quinn, C.P. (2006) Rapid, sensitive and specific lateral flow immunochromatographic device to measure anti-anthrax protective antigen immunoglobulin in serum and whole blood. Clin. Vaccine Immunol., 13(5): 541-546. 